\title{
Biological characteristics of the round goby, Neogobius melanostomus (Pallas, 1814), from different water bodies
}

\author{
Viktor O. Demchenko, Maria Y. Tkachenko
}

Received - 07 August 2016/Accepted - 22 March 2017. Published online: 31 March 2017; Inland Fisheries Institute in Olsztyn, Poland Citation: Demchenko V.O., Tkachenko M.Y. 2017 - Biological characteristics of the round goby, Neogobius melanostomus (Pallas, 1814), from different water bodies - Arch. Pol. Fish. 25: 51-61.

\begin{abstract}
The paper considers the ecological variability of the round goby, Neogobius melanostomus (Pall.), in different environments. The dietary spectrum and morphological variability of round goby populations were studied in two water bodies with different environmental conditions. The sizes and body weights of specimens were the largest in Obytichna Bay and the smallest in Kakhovka Reservoir. Differences in the morphological indices of gobies from freshwater and marine bodies of water were determined using discriminant analysis. At the study sites the round goby chiefly fed on benthic organisms that varied in species composition and energy equivalent. A significant portion of the diet comprised bivalves such as Abra ovata, Cerastoderma glaucum, and Parvicardium exiguum, which have the highest energy capacity. The average energy equivalent indices of prey items were higher in Obytichna Bay and the lowest in Kakhovka Reservoir.
\end{abstract}

Keywords: round goby, Sea of Azov, Kakhovka Reservoir, Obytichna Bay, morphometric analysis, age structure, diet

\footnotetext{
V.O. Demchenko

The Interdepartmental Laboratory of Ecosystem Monitoring of the Azov Sea Basin at the Institute of Marine Biology and B.

Khmelnytskyi Melitopol State Pedagogical University, Melitopol, Ukraine

M.Y. Tkachenko [ [ڤ]

Tavria State Agrotechnological University

18 B. Khmelnytskoho Ave., Melitopol, Zaporizhzhia Reg., 72312, Ukraine

e-mail: tkachenkomaria@mail.ru
}

\section{Introduction}

The round goby, Neogobius melanostomus (Pall.), is a bottom euryhaline species of the family Gobiidae. It is widespread in the Sea of Azov and the Black Sea, and to date it has considerably extended its range of distribution. In the 1960 s, the round goby was first recorded in water bodies of North America (Ray and Corkum 2001, Gutowsky and Fox 2011, 2012, Nolte 2011, Kornis et al. 2012). Its range had also extended into Europe. The round goby was first noted in the Baltic Sea in Puck Bay in 1990 (Sapota and Skóra 2005), where it had probably been introduced via ballast water of ships traveling through canals connecting the Black and Caspian seas to the Baltic Sea (Kornis et al. 2012). Currently, this species is common in the Dutch part of the Rhine River, while other sources report the round goby in water bodies in Germany, Poland, the Czech Republic, Hungary, Slovakia, Romania, Croatia, and Sweden (Piria et al. 2011, Verreycken et al. 2011).

This species exhibits a wide tolerance to environmental conditions, broad feeding habits, aggressive behavior, and parental care (Balážová-Lavrinčíková and Kováč 2007). The round goby is very flexible with variations in salinity from freshwater to brackish and salt water bodies. Since the species is actively extending its range to freshwater areas of Ukraine and other European countries, the study of its biological

(c) Copyright by Stanisław Sakowicz Inland Fisheries Institute in Olsztyn.

(c) 2017 Author(s). This is an open access article licensed under the Creative Commons Attribution-NonCommercial-NoDerivs License (http://creativecommons.org/licenses/by-nc-nd/3.0/). 
characteristics under various ecological conditions is required. It has already been established that a certain degree of round goby morphological variability depends on the salinity of the water body it inhabits (Tkachenko and Demchenko 2015), and that this variability is accompanied by changes in growth rates and dietary spectrum (Tkachenko and Demchenko 2014). Therefore, a comparative analysis of the morphological variability and biological characteristics of the species in different types of water bodies is important to predict the further distribution of the species both in Europe and other regions.

\section{Material and Methods}

The material was collected during June-August 2004-2012. The model sites were Kakhovka Reservoir (a shallow, lake-like water area near the village of Skelki, characterized by moderate temperatures, no pronounced stratification, $0.14 \%$ salinity) and Obytichna Bay (10-11\%o salinity) (Fig. 1). A total of

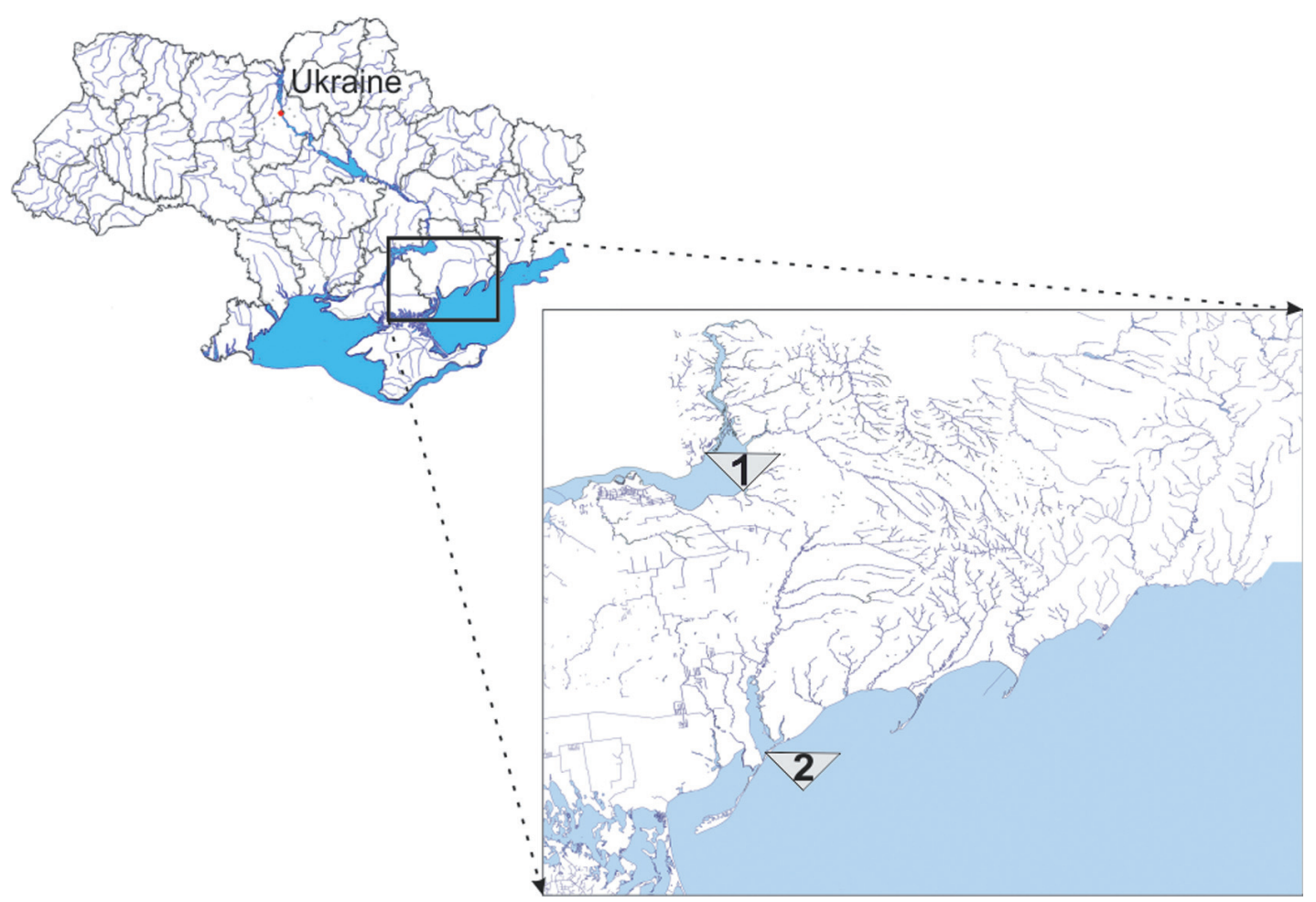

760 specimens of round goby from Kakhovka Reservoir (514 specimens) and Obytichna Bay (246 specimens) were processed for the morphological and biological analysis. Thirty-eight plastic traits were studied during the morphological analysis (Fig. 2) (Pravdin 1966, Zabroda and Diripasko 2009). The complete biological analysis determined total length (TL), standard length (SL), body weight, and fish age (Chugunova 1959). Since the round goby is sexually dimorphic, which is apparent in their body sizes and spawning appearance, these fish specimens were not included in the analysis. Throughout their ontogenesis and the seasonal dynamics of morphological changes, the round goby exhibits broad variability because of their reproductive characteristics. Thus, males exhibit black fin coloration, and the enlargement of fins and head size, while body width and height increase in females. Therefore, to avoid inaccuracies in calculations, discriminant and cluster analyses were performed among specimens of the same age $-2-2+(n=760)$, and fish in mating color were not included in the analysis. Morphological traits were measured from the left size of the body

Figure 1. Study area. 1 - Kakhovka Reservoir, 2 - Obytichna Bay. 



Figure 2. Scheme of round goby (N. melanostomus) measurements (plastic traits). TL - total length, SL - standard length, H - maximum body depth, $\mathrm{h}$ - caudal peduncle depth, iH - maximum body width, ih - caudal peduncle width, aD - ante-dorsal distance, pD post-dorsal distance, $\mathrm{pl}$ - length of caudal peduncle, $\mathrm{aP}$ - ante-pectoral distance, aV - ante-ventral distance, aA - ante-anal distance, $\mathrm{V}$-A - ventro-anal distance, pl - caudal peduncle length, ID1 - first dorsal fin base length, hD1 - first dorsal fin depth, ID2 - second dorsal fin base length, hD2 - second dorsal fin depth, lA - anal fin base length, hA - anal fin base depth, lP - pectoral fin length, iP - pectoral fin depth, lV - ventral fin length, iV - ventral fin base depth, IC - caudal fin length, HL - head length, hcz - head depth, ic - head width, ao ante-orbital distance, o - eye diameter, op - post-orbital distance, io - inner-orbital distance, lm - upper jaw length, lmd - lower jaw length, or - eye and the angle of the jaw distance, hop - cheeks depth, ir - mouth length, hco - head depth through the middle of the eye, ist - isthmus width.

using a caliper to the nearest $0.1 \mathrm{~mm}$. The plastic features were normalized for SL, and measurements performed on the head were normalized to the length of the head (HL) for mathematical analysis.

The dietary study was based on the examination of the contents of 78 fish stomachs (33 from Kakhovka Reservoir and 45 from Obytichna Bay). The taxonomy of prey species was determined using an identification guide (Anistratenko et al. 2011). The length of prey items was determined with an MBS-10 binocular microscope. The nomograms illustrating the body weights of aquatic organisms by their size and body shape were used to calculate the reconstructed weight of the prey items (Chislenko 1968).

The calorie content of prey items was assessed with the dependence method for the calculation of the energy equivalent of body weight (Alexandrov
2001). Simultaneously, the body weight reconstruction of prey items based on benthos samples from study sites was done to avoid error in calculations of prey weight. The food consumption index was calculated with the following formula (Ricker 1968):

$$
I=\left(W W \times B W^{1}\right) \times 100 \%,
$$

where $\mathrm{WW}$ - the reconstructed wet weight of the food component; BW - the fish body weight

The index of relative importance of prey items was calculated as follows:

$$
I R I=(M+N) \times F,
$$

where $\mathrm{M}$ is the biomass of prey item (\% of total restored biomass of all prey items in the fish diet); $\mathrm{N}$ - the number of prey items ( $\%$ of the total number of all prey items in the fish diet); F - frequency of the prey item in 
Table 1

Comparative characteristics of plastic traits of round goby (N. melanostomus) from water bodies with different salinity

\begin{tabular}{|c|c|c|c|c|c|c|c|c|c|}
\hline \multirow[b]{3}{*}{ Trait } & & \multirow{2}{*}{\multicolumn{3}{|c|}{$\begin{array}{l}\text { Obytichna Bay } \\
\text { Males }(n=95)\end{array}$}} & \multicolumn{3}{|c|}{ Kakhovka Reservoir } & \multirow[b]{2}{*}{ U-test } & \multirow[b]{3}{*}{$\mathrm{p}$} \\
\hline & & & & & Males $(n=28$ & & & & \\
\hline & & mean $\pm \mathrm{SE}$ & $\min -\max$ & $\mathrm{CV}$ & mean $\pm \mathrm{SE}$ & $\min -\max$ & $\mathrm{CV}$ & $\mathrm{Z}$ & \\
\hline SL & & $11.5 \pm 0.2$ & $7.6-15.5$ & 15.7 & $10.1 \pm 0.1$ & $5.1-12.9$ & 13.6 & 6.44 & $<0.001$ \\
\hline \multirow[t]{4}{*}{ Tail } & $\mathrm{pl}$ & $20.5 \pm 0.1$ & $17.2-25.0$ & 6.6 & $20.3 \pm 0.1$ & $16.5-26.9$ & 7.2 & 0.95 & 0.34 \\
\hline & $\mathrm{pD}$ & $19.0 \pm 0.2$ & $14.0-22.8$ & 7.8 & $18.2 \pm 0.1$ & $10.2-21.6$ & 7.6 & 4.37 & $<0.001$ \\
\hline & $\mathrm{h}$ & $11.2 \pm 0.1$ & $9.0-12.8$ & 6.9 & $10.6 \pm 0.1$ & $8.5-22.2$ & 10.5 & 6.25 & $<0.001$ \\
\hline & ih & $3.7 \pm 0.1$ & $2.3-5.2$ & 19.2 & $3.8 \pm 0.1$ & $2.1-5.5$ & 16.6 & 1.95 & 0.05 \\
\hline \multirow[t]{8}{*}{ Body } & $\mathrm{H}$ & $22.0 \pm 0.3$ & $15.0-35.1$ & 11.0 & $20.8 \pm 0.1$ & $14.3-26.2$ & 10.4 & 3.98 & $<0.001$ \\
\hline & $\mathrm{iH}$ & $18.6 \pm 0.2$ & $13.7-23.2$ & 9.6 & $18.5 \pm 0.1$ & $10.6-22.3$ & 9.2 & 0.56 & 0.58 \\
\hline & $\mathrm{aD}$ & $33.4 \pm 0.2$ & $29.3-38.0$ & 4.8 & $33.5 \pm 0.1$ & 26.1-39.5 & 4.7 & 0.21 & 0.84 \\
\hline & $\mathrm{aP}$ & $31.8 \pm 0.1$ & $27.4-34.5$ & 3.6 & $32.1 \pm 0.1$ & $28.0-38.0$ & 4.2 & 1.37 & 0.17 \\
\hline & $\mathrm{aV}$ & $31.2 \pm 0.2$ & $26.2-36.9$ & 6.7 & $30.6 \pm 0.1$ & $27.0-35.4$ & 4.5 & 2.19 & 0.03 \\
\hline & $\mathrm{aA}$ & $56.7 \pm 0.4$ & $30.9-62.3$ & 6.2 & $57.7 \pm 0.2$ & $32.7-68.7$ & 4.5 & 3.28 & $<0.001$ \\
\hline & $\mathrm{V}-\mathrm{A}$ & $24.1 \pm 0.2$ & 21.9-34.9 & 9.8 & $28.9 \pm 0.2$ & $21.0-55.4$ & 9.8 & 5.61 & $<0.001$ \\
\hline & PV & $18.0 \pm 0.2$ & $14.2-20.9$ & 8.2 & $16.7 \pm 0.1$ & $11.1-23.7$ & 10.2 & 6.21 & $<0.001$ \\
\hline \multirow[t]{5}{*}{ Dorsal fins } & ID1 & $17.5 \pm 0.2$ & $10.5-22.1$ & 9.8 & $17.6 \pm 0.1$ & $11.8-21.4$ & 9.5 & 0.48 & 0.63 \\
\hline & $\mathrm{hD} 1$ & $12.1 \pm 0.2$ & $7.7-15.9$ & 14.9 & $12.2 \pm 0.1$ & $7.3-16.7$ & 13.0 & 0.40 & 0.69 \\
\hline & ID2 & $32.0 \pm 0.2$ & $28.2-34.9$ & 5.4 & $32.5 \pm 0.1$ & $25.8-37.5$ & 6.9 & 2.05 & 0.04 \\
\hline & $\mathrm{hD} 2$ & $11.3 \pm 0.2$ & $8.4-16.8$ & 14.2 & $11.6 \pm 0.1$ & $6.4-15.9$ & 13.6 & 2.22 & 0.03 \\
\hline & ID1-ID2 & $1.3 \pm 0.1$ & $0.0-6.3$ & 77.7 & $1.0 \pm 0.1$ & $0.0-2.9$ & 62.0 & 2.49 & 0.01 \\
\hline \multirow[t]{7}{*}{ Ventral and thoracic fins } & $1 \mathrm{~A}$ & $25.2 \pm 0.2$ & $21.0-29.4$ & 5.9 & $25.1 \pm 0.1$ & $20.5-34.3$ & 6.6 & 0.44 & 0.66 \\
\hline & hA & $9.7 \pm 0.1$ & $5.5-14.4$ & 14.6 & $9.8 \pm 0.1$ & $5.7-13.3$ & 12.3 & 1.67 & 0.09 \\
\hline & IP & $29.3 \pm 0.2$ & $24.7-33.2$ & 5.8 & $26.1 \pm 0.1$ & $20.2-33.5$ & 7.7 & 11.44 & $<0.001$ \\
\hline & $\mathrm{iP}$ & $12.1 \pm 0.1$ & $9.8-13.7$ & 5.5 & $11.5 \pm 0.1$ & $9.5-13.9$ & 5.8 & 6.83 & $<0.001$ \\
\hline & iv & $7.0 \pm 0.1$ & $5.8-8.5$ & 6.9 & $6.8 \pm 0.1$ & $4.2-8.3$ & 8.5 & 3.18 & $<0.001$ \\
\hline & $\mathrm{LV}$ & $21.2 \pm 0.1$ & $17.8-24.4$ & 5.6 & $19.6 \pm 0.1$ & $9.5-23.5$ & 6.5 & 9.72 & $<0.001$ \\
\hline & IC & $22.2 \pm 0.1$ & $18.8-25.3$ & 6.0 & $21.1 \pm 0.1$ & $16.6-24.8$ & 6.2 & 6.60 & $<0.001$ \\
\hline \multirow[t]{14}{*}{ Head } & $\mathrm{HL}$ & $28.3 \pm 0.1$ & $25.2-31.7$ & 4.3 & $28.7 \pm 0.1$ & $20.4-36.5$ & 5.3 & 2.85 & $<0.001$ \\
\hline & hcz & $77.3 \pm 0.6$ & 61.9-89.1 & 8.2 & $72.4 \pm 0.3$ & $54.2-89.2$ & 6.8 & 7.01 & $<0.001$ \\
\hline & hco & $58.0 \pm 0.6$ & $50.0-75.2$ & 9.3 & $57.7 \pm 0.3$ & $44.1-84.2$ & 8.5 & 0.61 & 0.54 \\
\hline & hop & $44.3 \pm 0.4$ & $34.5-52.9$ & 8.9 & $45.8 \pm 0.2$ & $33.2-64.2$ & 7.8 & 3.31 & $<0.001$ \\
\hline & ao & $34.9 \pm 0.3$ & $22.7-42.5$ & 9.7 & $32.3 \pm 0.2$ & $24.4-42.8$ & 9.4 & 6.60 & $<0.001$ \\
\hline & op & $51.9 \pm 0.5$ & $41.2-71.3$ & 9.8 & $51.2 \pm 0.3$ & $38.5-72.2$ & 8.5 & 0.62 & 0.54 \\
\hline & 0 & $19.3 \pm 0.2$ & $13.8-24.8$ & 12.2 & $20.6 \pm 0.1$ & $14.7-33.7$ & 11.2 & 4.36 & $<0.001$ \\
\hline & io & $31.2 \pm 0.4$ & $20.0-42.7$ & 12.0 & $29.3 \pm 0.2$ & $22.0-35.8$ & 9.7 & 4.33 & $<0.001$ \\
\hline & or & $24.7 \pm 0.3$ & $17.2-31.5$ & 12.5 & $25.2 \pm 0.2$ & $14.8-37.4$ & 13.5 & 1.38 & 0.17 \\
\hline & $\operatorname{lm}$ & $32.2 \pm 0.3$ & $25.2-40.8$ & 9.5 & $31.9 \pm 0.2$ & $23.8-53.5$ & 10.0 & 0.58 & 0.56 \\
\hline & $\operatorname{lmd}$ & $37.5 \pm 0.3$ & $28.6-45.4$ & 8.3 & $37.9 \pm 0.2$ & $28.0-58.8$ & 8.9 & 0.84 & 0.40 \\
\hline & ir & $47.1 \pm 0.6$ & $34.3-63.6$ & 11.8 & $48.9 \pm 0.3$ & $23.7-76.5$ & 10.5 & 3.32 & $<0.001$ \\
\hline & ic & $83.5 \pm 0.8$ & $53.7-104.0$ & 9.3 & $80.5 \pm 0.4$ & $53.3-117.6$ & 8.0 & 3.96 & $<0.001$ \\
\hline & ist & $33.1 \pm 0.7$ & $18.7-46.4$ & 20.7 & $26.9 \pm 0.3$ & $13.6-46.8$ & 17.6 & 7.44 & $<0.002$ \\
\hline
\end{tabular}


Cont. Table 1

\begin{tabular}{|c|c|c|c|c|c|c|c|c|c|}
\hline \multirow[b]{3}{*}{ Trait } & & \multicolumn{3}{|c|}{ Obytichna Bay } & \multicolumn{3}{|c|}{ Kakhovka Reservoir } & \multirow[b]{2}{*}{ U-test } & \multirow[b]{3}{*}{$\mathrm{p}$} \\
\hline & & \multicolumn{3}{|c|}{ Females $(\mathrm{n}=151)$} & \multicolumn{3}{|c|}{ Females $(\mathrm{n}=231)$} & & \\
\hline & & mean $\pm \mathrm{SE}$ & $\min -\max$ & $\mathrm{CV}$ & mean $\pm \mathrm{SE}$ & $\min -\max$ & $\mathrm{CV}$ & $\mathrm{Z}$ & \\
\hline SL & & $10.4 \pm 0.1$ & $7.0-15.1$ & 13.5 & $7.8 \pm 0.1$ & $5.7-10.5$ & 12.4 & 13.98 & $<0.001$ \\
\hline Tail & $\mathrm{pl}$ & $20.4 \pm 0.1$ & $16.4-25.1$ & 7.5 & $20.2 \pm 0.1$ & $16.3-23.5$ & 6.7 & 1.31 & 0.19 \\
\hline & $\mathrm{pD}$ & $19.1 \pm 0.2$ & $15.3-39.0$ & 10.8 & $18.1 \pm 0.1$ & $14.4-22.7$ & 7.4 & 6.06 & $<0.001$ \\
\hline & $\mathrm{h}$ & $11.0 \pm 0.1$ & $8.9-16.9$ & 7.9 & $9.9 \pm 0.1$ & $8.1-11.5$ & 6.3 & 12.17 & $<0.001$ \\
\hline & ih & $3.5 \pm 0.1$ & $2.3-5.3$ & 19.7 & $3.9 \pm 0.1$ & $1.8-5.6$ & 15.9 & 5.43 & $<0.001$ \\
\hline Body & $\mathrm{H}$ & $22.3 \pm 0.2$ & $15.0-28.2$ & 9.3 & $21.0 \pm 0.2$ & $14.8-30.3$ & 12.1 & 5.25 & $<0.001$ \\
\hline & $\mathrm{iH}$ & $19.1 \pm 0.2$ & $13.3-23.5$ & 10.8 & $18.7 \pm 0.1$ & $14.2-23.2$ & 9.5 & 2.52 & 0.01 \\
\hline & $\mathrm{aD}$ & $33.9 \pm 0.1$ & $24.3-38.6$ & 4.6 & $33.3 \pm 0.1$ & $26.0-37.3$ & 4.4 & 4.61 & $<0.001$ \\
\hline & $\mathrm{aP}$ & $31.6 \pm 0.1$ & $17.4-34.0$ & 5.5 & $31.3 \pm 0.1$ & $13.8-34.7$ & 4.7 & 3.21 & $<0.001$ \\
\hline & $\mathrm{aV}$ & $30.7 \pm 0.1$ & $26.0-39.2$ & 5.5 & $30.2 \pm 0.1$ & $26.0-33.9$ & 4.6 & 3.12 & 0.002 \\
\hline & $\mathrm{aA}$ & $57.3 \pm 0.3$ & $19.9-65.9$ & 6.4 & $57.8 \pm 0.2$ & $47.9-65.1$ & 4.0 & 1.69 & 0.09 \\
\hline & V-A & $28.0 \pm 0.2$ & $21.9-35.2$ & 8.0 & $28.8 \pm 0.2$ & $23.6-35.0$ & 8.2 & 3.34 & $<0.001$ \\
\hline & PV & $18.2 \pm 0.1$ & $8.5-21.5$ & 9.5 & $16.2 \pm 0.1$ & $11.3-20.7$ & 11.0 & 10.15 & $<0.001$ \\
\hline Dorsal fins & ID1 & $17.5 \pm 0.1$ & $10.4-22.1$ & 10.2 & $17.3 \pm 0.1$ & $12.5-21.3$ & 8.8 & 1.37 & 0.17 \\
\hline & $\mathrm{hD} 1$ & $11.5 \pm 0.1$ & $7.1-16.8$ & 14.3 & $10.8 \pm 0.1$ & $7.9-14.8$ & 12.1 & 3.90 & 0.00 \\
\hline & $\mathrm{lD} 2$ & $31.7 \pm 0.1$ & $26.5-35.3$ & 4.6 & $32.1 \pm 0.1$ & $20.3-38.7$ & 6.0 & 2.30 & 0.02 \\
\hline & $\mathrm{hD} 2$ & $10.8 \pm 0.1$ & $6.9-19.5$ & 15.4 & $10.5 \pm 0.1$ & $7.4-16.6$ & 14.3 & 1.75 & 0.08 \\
\hline & 1D1-1D2 & $1.1 \pm 0.1$ & $0-9.0$ & 103.5 & $1.1 \pm 0.1$ & $0-4.4$ & 64.5 & 1.40 & 0.16 \\
\hline Ventral and thoracic fins & $1 \mathrm{~A}$ & $24.4 \pm 0.1$ & $20.6-32.9$ & 6.2 & $24.5 \pm 0.1$ & $13.5-38.7$ & 8.8 & 0.30 & 0.76 \\
\hline & hA & $9.5 \pm 0.1$ & $6.8-13.9$ & 14.1 & $9.0 \pm 0.1$ & $5.9-12.7$ & 13.1 & 3.14 & $<0.001$ \\
\hline & $\mathrm{IP}$ & $28.7 \pm 0.2$ & $19.0-33.6$ & 7.1 & $25.5 \pm 0.1$ & $20.7-31.4$ & 7.5 & 12.99 & $<0.001$ \\
\hline & iP & $11.9 \pm 0.1$ & $9.7-13.9$ & 5.7 & $10.9 \pm 0.1$ & $8.9-12.9$ & 6.0 & 11.81 & $<0.001$ \\
\hline & iv & $7.0 \pm 0.1$ & $5.5-11.3$ & 8.9 & $6.4 \pm 0.1$ & 4.4-7.6 & 10.2 & 9.25 & $<0.001$ \\
\hline & $\mathrm{LV}$ & $21.7 \pm 0.1$ & $16.0-24.9$ & 6.0 & $20.0 \pm 0.1$ & $16.1-23.6$ & 6.2 & 11.32 & $<0.001$ \\
\hline & $\mathrm{IC}$ & $22.0 \pm 0.1$ & $16.0-31.7$ & 7.6 & $20.6 \pm 0.1$ & $16.8-24.0$ & 6.7 & 8.83 & $<0.001$ \\
\hline Head & $\mathrm{HL}$ & $27.9 \pm 0.1$ & $16.1-30.8$ & 5.6 & $27.5 \pm 0.1$ & 23.2-30.7 & 4.6 & 4.34 & $<0.001$ \\
\hline & hcz & $79.9 \pm 0.6$ & 58.8-133.3 & 9.3 & $74.8 \pm 0.4$ & $55.4-89.9$ & 7.3 & 7.83 & $<0.001$ \\
\hline & hco & $56.1 \pm 0.4$ & $39.7-93.9$ & 9.1 & $56.0 \pm 0.3$ & $45.1-75.9$ & 7.3 & 0.48 & 0.63 \\
\hline & hop & $44.0 \pm 0.5$ & $36.0-99.4$ & 12.9 & $45.3 \pm 0.2$ & $37.1-55.2$ & 6.6 & 5.03 & $<0.001$ \\
\hline & ao & $34.9 \pm 0.4$ & $22.2-75.8$ & 13.8 & $31.4 \pm 0.2$ & $22.9-41.8$ & 9.6 & 9.27 & $<0.001$ \\
\hline & op & $52.7 \pm 0.5$ & $39.0-90.9$ & 11.2 & $52.1 \pm 0.3$ & $38.8-64.4$ & 8.1 & 0.66 & 0.51 \\
\hline & 0 & $21.1 \pm 0.2$ & $16.0-40.9$ & 13.0 & $24.2 \pm 0.2$ & $17.4-34.0$ & 11.0 & 10.63 & $<0.001$ \\
\hline & io & $32.4 \pm 0.3$ & $20.4-53.0$ & 12.2 & $29.1 \pm 0.2$ & $16.3-40.4$ & 10.7 & 8.53 & $<0.001$ \\
\hline & or & $23.6 \pm 0.3$ & $15.4-36.1$ & 14.9 & $21.0 \pm 0.2$ & $11.0-28.9$ & 13.2 & 7.59 & $<0.001$ \\
\hline & $\operatorname{lm}$ & $30.2 \pm 0.3$ & $24.8-51.5$ & 10.4 & $29.1 \pm 0.2$ & $21.3-40.0$ & 8.2 & 3.05 & $<0.001$ \\
\hline & $\operatorname{lmd}$ & $36.0 \pm 0.3$ & $29.9-56.8$ & 8.9 & $34.5 \pm 0.2$ & $23.9-45.8$ & 7.5 & 4.55 & $<0.001$ \\
\hline & ir & $44.6 \pm 0.3$ & $35.8-75.8$ & 9.5 & $44.7 \pm 0.3$ & $33.5-58.9$ & 9.1 & 0.85 & 0.39 \\
\hline & ic & $84.0 \pm 0.7$ & $31.1-140.2$ & 10.5 & $79.6 \pm 0.3$ & $66.8-99.6$ & 6.4 & 7.62 & $<0.001$ \\
\hline & ist & $33.9 \pm 0.7$ & 18.5-64.4 & 24.6 & $28.8 \pm 0.3$ & 17.4-42.2 & 15.8 & 6.11 & $<0.002$ \\
\hline
\end{tabular}


Table 2

Total length and body weight of male and female round goby (N. melanostomus) from Kakhovka Reservoir and Obytichna Bay

\begin{tabular}{|c|c|c|c|c|c|c|c|c|c|c|}
\hline \multirow[b]{2}{*}{ Water body } & \multirow[b]{2}{*}{ Sex } & \multirow[b]{2}{*}{$\mathrm{N}$} & \multicolumn{4}{|c|}{ Total length (cm) } & \multicolumn{4}{|c|}{ Body weight (g) } \\
\hline & & & $\min$ & $\max$ & Mean & SE & $\min$ & $\max$ & Mean & SE \\
\hline \multirow[t]{3}{*}{ Obytichna Bay } & female & 1401 & 5.0 & 15.0 & 9.2 & 0.4 & 3.0 & 91.0 & 21.9 & 0.3 \\
\hline & male & 1807 & 6.0 & 18.0 & 11.5 & 0.1 & 3.0 & 151.0 & 46.0 & 0.7 \\
\hline & Total & 3208 & 5.0 & 18.0 & 11.0 & 0.1 & 3.0 & 151.0 & 35.8 & 0.5 \\
\hline \multirow[t]{3}{*}{ Kakhovka Reservoir } & female & 434 & 5.0 & 10.0 & 7.2 & 0.1 & 3.0 & 38.0 & 11.2 & 0.3 \\
\hline & male & 448 & 5.0 & 13.0 & 9.1 & 0.1 & 2.0 & 70.0 & 24.6 & 0.7 \\
\hline & Total & 882 & 6.0 & 13.0 & 9.0 & 0.1 & 2.0 & 70.0 & 18.0 & 0.5 \\
\hline
\end{tabular}

stomach contents (\% of the total number of the studied stomachs) (Zamorov and Chernikova 2011).

The reliability of differences according to the indices of plastic traits was estimated using the Wilcoxon-Mann-Whitney U test. Cluster analysis of the round goby samples was performed by the cumulative effect of plastic trait loads and further summation for each case. Statistical analysis was performed with Statistica 7.0 (StatSoft, Inc.), Microsoft Excel, and Access 2010.

\section{Results}

\section{Morphological variability}

The results indicate that the coefficient values of the plastic traits in both males and females from Obytichna Bay prevail over those in specimens from Kakhovka Reservor. The dorsal fin values of the males from Kakhovkse Reservoir were somewhat higher, while the ventral fins were larger in males from Obytichna Bay (Table 1). General growth in the size of the caudal peduncle was noted, because of the shortened dorsal fins (ID1, 1D2) and dorsal length (aD). The ratio between length traits of ventral fin (lA) and the sucker (iv, LV) was polar, because of the considerable reduction of ventro-anal distance and, correspondingly, ante-anal distance (aA). The sizes of caudal peduncles and fins were larger compared to the fish from Kakhovka Reservoir. Males from Obytichna Bay had smaller head length (HL) and increased head height at the nape (hcz) and head height across the middle of the eye (hco). In spite of these parameters, ante-orbital length (ao) and postorbital length (op) were greater, with a general reduction in eye diameter (o). It should be noted that the fish from the bay had longer upper jaws $(\mathrm{lm})$, whereas the fish from the reservoir had longer lower jaws (lmd).

The distribution of traits in females from the water bodies studied was generally similar to those in males, though some differences were noted. Thus, females from Obytichna Bay had larger dorsal fin parameters (lD1, hD1, hD2), except for the length of the second dorsal fin (ID2). There were also differences in head traits, namely females from the bay had greater head length (HL) and smaller jaw length (lmd). The discriminant analysis of plastic traits using three standard variants showed differences between samples of the two sexes (Figure 3). As is clear from the chart, differences among samples themselves from different water bodies are on axis 1 , while those between groups according to the sex are on axis 2. Thus, the smallest differences between males and females are in the sample from Obytichna Bay. Cluster analysis showed similar distribution: the first cluster was formed by specimens from the bay, and the second one by specimens from Kakhovka Reservoir (Figure 4). 


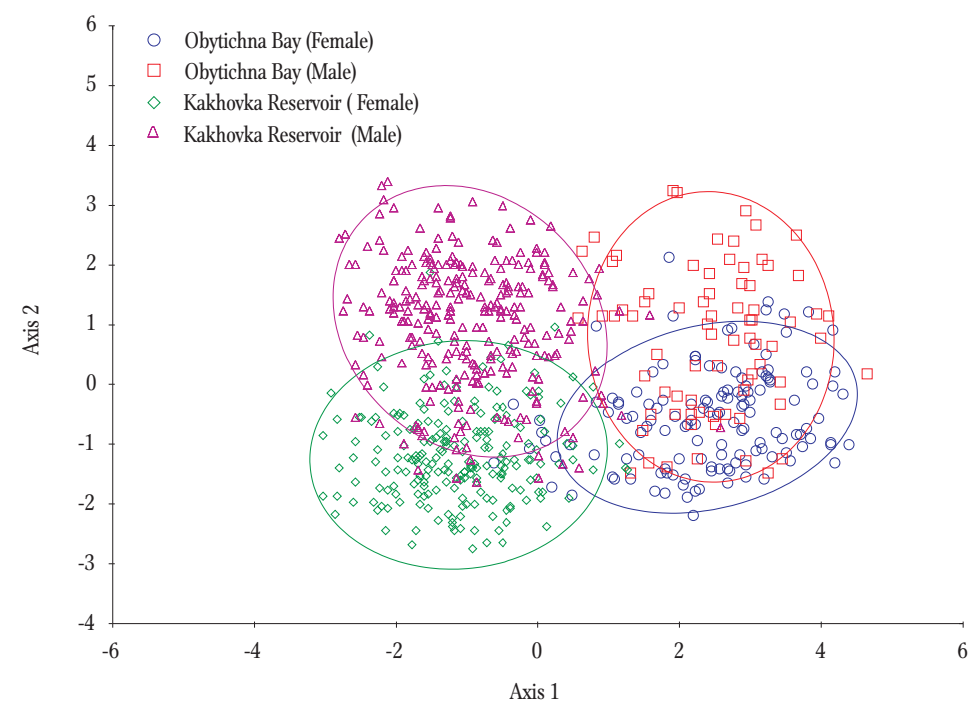

Figure 3. Discriminant analysis of differences in round goby (N. melanostomus) samples.

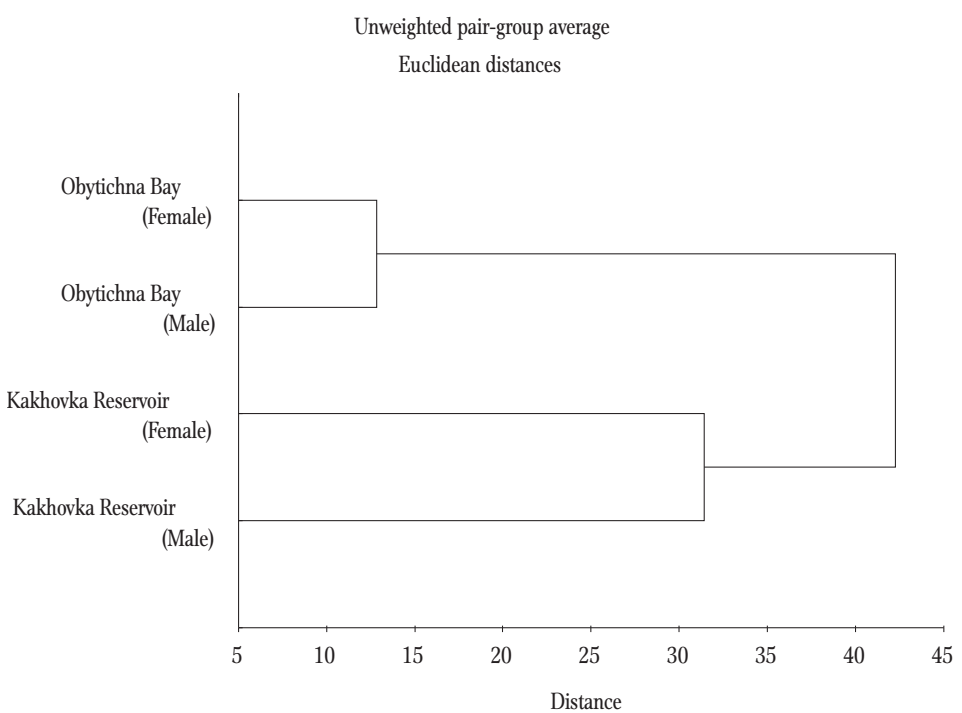

Figure 4. Clyster analysis of differences in round goby ( $N$. melanostomus) from the Kakhovka Reservoir and Obytichna Bay.

\section{Standard length-body weight, sex and age structure}

The analysis of average body sizes (according to standard length) showed that the males dominated the females in both water bodies, which is typical for this species (Table 2). When comparing the sexes, it should be noted that both females and males from the bay were bigger than those from the reservoir. Thus, the sizes of the males from the bay and reservoir differ by almost $20.87 \%$, while those of the females differed by $21.74 \%$. The total difference between the round goby from the two areas was $23.25 \%$. The goby from the reservoir and the bay also differed in body weight; female body weight in the bay was greater by $58.24 \%$, while that of the male was $53.64 \%$.

The age structure was represented by five age groups in Obytichna Bay and four in Kakhovka Reservoir. Among the females from Kakhovka Reservoir, the most common age group was $2-2+$, and the rarest was $4-4+$. The situation with males was similar, but the group 4-4+ was totally absent; instead, the $0+$ age group was recorded in the catches (Table 3$)$. The age groups of $2-2+$ and 3-3+ prevailed in Obytichna Bay. Additionally, the percentage of 4-4+ gobies was higher in the bay than in the reservoir.

\section{Diet and energy equivalent}

The diet of gobies from Obytichna Bay included seven prey taxa. Among them, Abra ovata, Cerastoderma glaucum, and Parvicardium exiguum dominated in number and biomass (Table 4). A. ovata had the highest frequency of occurrence at $81.3 \%$. The dietary spectrum of gobies in Kakhovka Reservoir was narrow, and the prey belonged to two taxa - representatives of Amphipoda and D. polymorpha, with the latter dominating all parameters.

The index of relative importance (IRI) was used to assess the individual prey components in the goby diet (Table 4). High values were noted for A. ovata (13700.4\%) in the fish from Obytichna Bay, while $C$. umbonatum was the least important dietary component in this area (39\%). D. polymorpha was the most important in the diet of specimens from Kakhovka Reservoir (18460\%). The values of index of food 
Table 3

Age structure of round goby (N. melanostomus) in the Kakhovka Reservoir and Obytichna Bay

\begin{tabular}{llllllllllllll}
\hline & \multicolumn{1}{c}{ Memales } & \multicolumn{1}{c}{ Males } \\
\cline { 2 - 15 } Water body & $\mathrm{N}$ & $0+$ & $1-1+$ & $2-2+$ & $3-3+$ & $4-4+$ & $\mathrm{N}$ & $0+$ & $1-1+$ & $2-2+$ & $3-3+$ & $4-4+$ \\
\hline \hline Kakhovka Reservoir & 423 & - & 7.8 & 90.5 & 0.5 & 1.2 & 403 & 2.0 & 9.4 & 79.4 & 9.2 & - \\
Obytichna Bay & 583 & 0.2 & 0.2 & 70.5 & 22.1 & 6.7 & 730 & 0.3 & 1.6 & 48.8 & 31.8 & 17.5 \\
\hline \hline
\end{tabular}

consumption differed in the two water bodies. Higher consumption was observed in Obytichna Bay, where the average index was $3.87 \%$ (range of $1.62-6.08 \%$ ), while it was $1.8 \%(0.23-6.84 \%)$ in the goby from Kakhovka Reservoir.

The analysis of the energy equivalent of prey items in stomach contents of round goby from the studied water bodies showed that in Obytichna Bay the highest values were for P. exiguum (45.7 J), $M$. lineatus (14.5 J), C. glaucum (12.9 J), and A. ovata $(12.1 \mathrm{~J})$. Representatives of the family Gammaridae had higher average energy equivalent values (110.2 J) in Kakhovka Reservoir. However, their number in the fish diet was small, and, thus, the bivalve $D$. polymorpha had a higher energy capacity $(17.3 \mathrm{~J})$ (Table 5).

\section{Discussion}

The morphological differences revealed between the two populations of round goby indicate that the fish adapted to different abiotic conditions. This kind of variability has been investigated in many fish species, including the round goby (Bilko 1966, Smirnov 2001, Zabroda and Diripasko 2009). Although a majority of changes in morphological traits are known to be associated with the systems of movement,

Table 4

Number (N, \%), biomass (B, \%), frequency (F, \%) and index of relative importance (IRI, \%) of prey items from the round goby $(N$. melanostomus) diet in the Kakhovka Reservoir and Obytichna Bay

\begin{tabular}{|c|c|c|c|c|c|c|c|c|}
\hline \multirow[b]{2}{*}{ Taxon } & \multicolumn{4}{|c|}{ Obytichna Bay } & \multicolumn{4}{|c|}{ Kakhovka Reservoir } \\
\hline & $\mathrm{N}$ & $\mathrm{B}$ & $\mathrm{F}$ & IRI & $\mathrm{N}$ & $\mathrm{B}$ & $\mathrm{F}$ & IRI \\
\hline \multicolumn{9}{|l|}{ Bivalvia } \\
\hline Anadara inaequivalvis (Bruguière, 1789) & 5.0 & 9.8 & 6.3 & 93.2 & - & - & - & - \\
\hline Abra ovata (Philippi, 1836) & 86.7 & 81.8 & 81.3 & 13700.4 & - & - & - & - \\
\hline Cerastoderma glaucum (Poiret, 1789) & 25.3 & 27.5 & 62.5 & 3299.5 & - & - & - & - \\
\hline Cerastoderma umbonatum (Wood, 1850) & 2.1 & 1.0 & 12.5 & 39.0 & - & - & - & - \\
\hline Mytilaster lineatus (Gmelin, 1791) & 0.5 & 1.6 & 31.3 & 66.0 & - & - & - & - \\
\hline $\begin{array}{l}\text { Parvicardium exiguum } \\
\text { (Gmelin in Linnaeus, 1791) }\end{array}$ & 43.0 & 43.9 & 25.0 & 2171.3 & - & - & - & - \\
\hline Dreissena polymorpha (Pallas, 1771) & - & - & - & - & 96.0 & 95.0 & 92.3 & 18460 \\
\hline \multicolumn{9}{|l|}{ Gastropoda } \\
\hline Hydrobia sp. & 7.1 & 0.002 & 31.3 & 223.2 & - & - & - & - \\
\hline \multicolumn{9}{|l|}{ Amphipoda } \\
\hline Gammarus sp. & - & - & - & - & 39.0 & 25.0 & 7.7 & 490.9 \\
\hline
\end{tabular}


Table 5

Values of energy equivalents of prey items from stomach contents of round goby (N. melanostomus) from the Kakhovka Reservoir and Obytichna Bay

\begin{tabular}{|c|c|c|c|c|}
\hline \multirow[b]{2}{*}{ Taxon } & \multicolumn{2}{|c|}{ Obytichna Bay } & \multicolumn{2}{|c|}{ Kakhovka Reservoir } \\
\hline & mean $\pm \mathrm{SE}$ & $\min -\max$ & mean $\pm \mathrm{SE}$ & $\min -\max$ \\
\hline Anadara inaequivalvis & 18.7 & - & - & - \\
\hline Abra ovata & $12.1 \pm 0.29$ & $1.2-62.5$ & - & - \\
\hline Cerastoderma glaucum & $12.9 \pm 1.2$ & $0.9-64.5$ & - & - \\
\hline Cerastoderma umbonatum & $4.7 \pm 1.2$ & $2.3-6.5$ & - & - \\
\hline Mytilaster lineatus & $14.5 \pm 3.9$ & $0.2-22.8$ & - & - \\
\hline Parvicardium exiguum & $45.7 \pm 4.2$ & $1.2-70.2$ & - & - \\
\hline Dreissena polymorpha & - & - & $17.3 \pm 1.5$ & $0.1-96.8$ \\
\hline Hydrobia sp. & $0.1 \pm 0.01$ & 0.1 & - & - \\
\hline Gammarus sp. & - & - & 110.2 & - \\
\hline
\end{tabular}

nutrition, and reproduction, most of them are reflected in several processes simultaneously (Mitrofanov 1977). These differences suggest that separate populations form and acquire certain morphological traits. This process results from the survival of individuals in which variability goes in specific directions thereby leading to shifts in average indices in one direction or the other. In the case of the round goby, it is most clearly seen in the ratio between fin size and head length.

The variability of size indices $(\mathrm{lC}, \mathrm{IV}$, iv, iP, $\mathrm{IP}$, lD1, lD2, hD1, hD2, lA, hA) of traits responsible for fish movement is associated with various hydrological conditions in the water bodies studied. Changes in head size indices (hco, hop, lm, lmd, ir,) depend on the dietary range of the specimens. Therefore, the functional correspondence of specimens to certain hydrological conditions leads to changes in morphological traits. If the effects of these factors or the isolation of populations last for a long period, this variability, under the influence of natural selection, manifests these differences at the genetic level (Mitrofanov 1977).

The comparison of the marine and freshwater populations indicated that there were significant differences in size and age structures. A seasonal trend was noted in the sex structure, but no significant differences were observed. According to the research, the individuals from the Sea of Azov are larger than those from the fresh water. The average length of the marine species was $12.9 \mathrm{~cm}$, while that of the fish from Kakhovka Reservoir was only $9.9 \mathrm{~cm}$. The fish weight also differed. Plentiful food resources and other favorable environmental conditions in the Sea of Azov led to much faster growth rates in the marine fish compared to those in the freshwater fish. Since the round goby is a typical Ponto-Caspian species, the long history of transformation of the Sea of Azov and Black Sea fauna has rendered this species well adapted to inhabiting warm, polyhaline waters (Shiganova and Bulgakova 2000). With regard to penetrating into river ecosystems, this species cannot assimilate into this unusual environment. One of the reasons could be the poor forage base, which, in Kakhovka Reservoir, for example, cannot support the intensive growth of goby individuals.

The age structure of the freshwater and marine populations also differed significantly. The life cycle of the round goby is short (Gutowsky and Fox 2012, Azour et al. 2015), and the maximum age of 
specimens in the samples examined was 4 years. The dominant age group in both bodies of water was $2-2+$. The main difference between the populations from the reservoir and the sea was in the percentage of fish in the 1-1+ and 3-3 + age groups. According to research results, the Azov Sea population is aging, and it contains a considerable number of 3-3+ and 4-4+ specimens. Conversely, in Kakhovka Reservoir the percentage of this age group is much smaller. This suggests that the freshwater population of round goby is developing. In addition, the age structure of the fish population in Kakhovka Reservoir is affected by pressure exerted by freshwater predators.

Differences in dietary range between the fish from freshwater and those from marine waters is significant. This is evident in both species composition and the caloric indices of the prey items. Studies on the dietary spectrum of specimens from different parts of the Sea of Azov and from freshwater basins have proved a direct relationship between values of the food energy equivalent and the salinity of the water body inhabited by the species (the correlation coefficient is 0.8) (Tkachenko and Demchenko 2014). This, in turn, determined the growth of specimens. Therefore, freshwater reservoirs are potentially less suitable as round goby habitats.

\section{Conclusions}

The results of the current investigation permit drawing the following conclusions:

- round gobies (N. melanostomus) from water bodies with different environmental conditions demonstrate morphological differentiation. The analysis of reliable differences among round goby samples revealed 29 reliable traits among samples of females from Obytichna Bay and Kakhovka Reservoir and 24 traits among males;

- size-mass indices of round goby correspond to their habitats. Round goby from Obytichna Bay have greater mass and body sizes compared to those from Kakhovka Reservoir. The age groups of 2-2+ and 3-3+-year-old goby dominated the samples;
- the round goby diet in Obytichna Bay and Kakhovka Reservoir included representatives of Bivalvia, Gastropoda, and Gammaridae. According to their number and mass, the most important in the diet in the bay were A. ovata and M. lineatus, while in the reservoir it was $D$. polymorpha. The average values of food consumption of the round goby were $1.8 \%$ in the reservoir and $3.9 \%$ in the bay. The energy equivalent of prey items in the round goby's diet differed significantly between the bodies of water studied. Higher average values of energy equivalent for the totality of prey items in the stomach contents of round goby were noted in Obytichna Bay.

Author contribution. M.T. performed the statistical analysis, analyzed the data, and wrote the draft of the manuscript; V.D. supervised the research and wrote the final version of the manuscript. All the authors participated in organizing the research, fish sampling, morphometric measurements, and diet composition and age determinations.

\section{References}

Alexandrov B.G. 2001 - Caloric content of Black Sea invertebrates. II. Macrozoobenthos - Marine Ecology 56: 71-76 (in Russian).

Anistratenko V.V., Khaliman I.A., Anistratenko O.Yu. 2011 Mollusks of the Sea of Azov - Kyiv: Naukova Dumka, p. 171 (in Russian).

Azour F., Deurs M.V., Behrens J., Carl H., Hüssy K., Greisen K., Ebert R., Møller P.R. 2015 - Invasion rate and population characteristics of the round goby Neogobius melanostomus: effects of density and invasion history Aquat. Biol. 24: 41-52.

Balážová-L’avrinčíková M., Kováč V 2007 - Epigenetic context in the life-history of round goby Neogobius melanostomus from Slovak stretch of the Danube - In: Freshwater bioinvaders: profiles, distribution and threats (Ed.) F. Gherardi, Springer, Berlin: 275-287.

Bilko V.P. 1966 - Fishing gobies of the Dnieper-Bug estuary Synopsis for PhD thesis Ukrainian Academy of Sciences, Institute of Zoology, 20 p. (in Russian).

Chislenko L.L. 1968 - Nomograms for determination the weight of aquatic organisms according to the body size and shape - Nauka, Leningrad, p. 160 (in Russian). 
Chugunova N.I. 1959 - Guide on study of fish age and growth - Akad. Nauk SSSR, Moscow, p. 164 (in Russian).

Gutowsky L.F.G., Fox M.G. 2011 - Occupation, body size and sex ratio of round goby (Neogobius melanostomus) in established and newly invaded areas of an Ontario river Hydrobiologia 671: 27-37.

Gutowsky L.F.G., Fox M.G. 2012 - Intra - population variability of life - history traits and growth during range expansion of the invasive round goby, Neogobius melanostomus - Fish. Manage. Ecol. 19: 78-88.

Kornis M.S., Mercado-Silva N., Vander Zanden M.J. 2012 Twenty years of invasion: a review of round goby Neogobius melanostomus biology, spread and ecological implications - J. Fish Biol. 80: 235-285.

Mitrofanov V.P. 1977 - Ecological features of morphological analysis of fish - Alma-Ata: KazGU, p. 32 (in Russian).

Nolte A.W. 2011 - Dispersal in the course of an invasion Mol. Ecol. 20: 1803-1804.

Piria M., Šprem N., Jakovlić I., Tomljanović T., Matulić D., Treer T., Aničić I., Safner R. 2011 - First record of round goby, Neogobius melanostomus (Pallas, 1814) in the Sava River, Croatia - Aquat. Invasions 6: 153-157.

Pravdin I.F. 1966 - A guide to fish study - Food Industry, Moscow (in Russian).

Ray W.J., Corkum L.D. 2001 - Habitat and site affinity of the round goby - J. Great Lakes Res. 27: 329-334.

Ricker W.E. 1968 - Methods for assessment of fish production in fresh waters -International Biological Program Handbook No. 3. Blackwell Scientific Publications, Oxford and Edinburgh, p. 348.

Sapota M.R., Skóra K.E. 2005 - Spread of alien (non-indigenous) fish species Neogobius melanostomus in the Gulf of Gdansk (south Baltic) - Biol. Invasions 7: 157-164.

Shiganova T.A., Bulgakova Y.V. 2000 - Effects of gelatinous plankton on Black Sea and Sea of Azov fish and their food resources - ICES J. Mar. Sci. 57: 641-648.

Smirnov A.I. 2001 - The round goby Neogobius melanostomus (Pisces, Gobiidae) is found outside of its area: reasons, distribution rate, probable after-effects Vestn. Zool. 5: 71-77 (in Russian).

Tkachenko M.Yu., Demchenko N.A. 2014 - Diet composition of round goby (Neogobius melanostomus (Pallas, 1814) under different ecological conditions - Mar. Ecol. J. 4: 64-70 (in Ukrainian).

Tkachenko M.Yu., Demchenko V.O. 2015 - Biological characteristics of round goby Neogobius melanostomus (Pallas, 1814) in the Utlyutskyy Estuary of the Sea of Azov - Odesa National University Herald, Biology, 20: 151-160 (in Ukrainian).

Verreycken H., Breine J. Jan., Snoeks J., Belpaire C. 2011 First record of the round goby. Neogobius melanostomus (Actinopterygii: Perciformes: Gobiidae) in Belgium Acta Ichthyol. Pisc. 41: 137-140

Zabroda T.A., Diripasko O.A. 2009 - Estimation of sexual distinctions in morphological features of round goby Neogobius melanostomus (Pallas, 1814) of Sea of Azov Visnyk of Zaporizhzhya National University, 2: 41-47 (in Russian).

Zamorov V., Chernikova S. 2011 - Diet analysis of round-goby Neogobius melanostomus (Pallas) in the coastal waters of Odessa Bay (The Black Sea) - Odessa National University Herald, Biology, 16: 38-44 (in Ukrainian). 